\title{
Brazilian Congress, 2014 elections and governability
}

\section{challenges ${ }^{*}$}

\author{
Fabiano Santos
}

Universidade do Estado do Rio de Janeiro, Brazil

\author{
Júllio Canello \\ PhD Candidate, Universidade do Estado do Rio de Janeiro, Brazil
}

This research note examines the results of the 2014 elections focusing on the National Congress. Its main objective is to ponder over common claims and predictions regarding the future of Brazilian politics. Beyond agreements and alliances involved in the electoral dispute, President Dilma Rousseff once again shall face the political challenges and dilemmas of Brazilian presidentialism, namely, how to create and manage government coalitions capable of implementing a coherent political program with a fragmented and heterogeneous Congress. The critical examination of the current hypotheses on the latest elections, especially concerning parliamentary fragmentation and a shift towards the right-wing, will serve as a compass attempting to formulate possible answers to such a fundamental problem in Brazilian politics.

Keywords: Elections; national congress; parties; Rousseff administration; coalition.

he following text is a research paper and as such, it does not intend
to formulate a closed theoretical argument, thereby developing testable hypotheses; moreover, it does not claim to produce an empirical analysis

(*) http://dx.doi.org/10.1590/1981-38212014000200005

For replication, see http://bpsr.org.br/files/arquivos/Banco_Dados_Santos_Canello.htm. This research note is the result of continuous analysis of the 2014 electoral results for the federal legislature with the support of the Center for Congressional Studies (Núcleo de Estudos sobre o Congresso - NECON) at IESP-UERJ. We are grateful to BPSR's anonymous reviewers for their comments and suggestions. 
of propositions. Its purpose is only to describe, in a minimally analytical form, the electoral results of 2014, focusing on the dispute for the seats of the National Congress. Although it is not our intention to promote a critical report of the literature, from this reading, it is possible to ponder over the claims and predictions of the columnists and analysts of Brazilian politics regarding the factors that will characterize the political process of the country, starting in 2015. Essentially, our objective is to discuss the following more general question: beyond the agreements and alliances that involved the electoral dispute, President Dilma Rousseff once again will face the usual political challenge of Brazilian presidentialism, i.e., to create and manage government coalitions capable of implementing a coherent program with a fragmented and heterogeneous Congress. Provisional answers to this issue will be formulated through a critical exam of the current hypotheses about the last elections in Brazil, including themes such as the increase in fragmentation, the supposed expansion of conservatives in the Legislative branch combined with a reduction of the left, and the supposed reduction of the potential government coalition.

This paper is subdivided into two other sections, followed by brief conclusions. First, we will describe the Congress elected in 2014 in terms of party seats, compare it with its composition before elections, and evaluate the changes in the size of the government coalition. We will then discuss the evolution of the parliament in terms of its ideological profile, considering the argument about the expansion of right-wing parties and their recent evolution in the legislative branch. Finally, we will briefly debate a few governability challenges the President faces and evaluate scenarios in terms of legislative agenda.

\section{Electoral results and the new Congress}

One of the fundamental aspects of governability in the next term will be the political atmosphere that the President finds in the National Congress. What kind of support will be possible? Where will she face resistance? And relative to which policies? In this paper, we consider it possible to project future scenarios on the basis of the recently elected Chamber of Deputies and Federal Senate by comparing it with the most recent legislatures. Although the size of the parties 
depends on the decisions made by the Electoral Justice ${ }^{1}$ and on the political dynamics at the beginning of 2015 regarding the composition of the ministries and state secretariats (which could change the numerical composition of the federal legislative branch), the parties are already showing the size of their representation for the next term.

In general terms, the balance of party seats seems to have been a surprise for a good part of the pre-election analyses. The results of the ballot boxes diverged from at least two projections-the one published by the Inter-Parliamentary Advisory Department (DIAP) and the estimates published by the Center for Congressional Studies (NECON) ${ }^{2}$. In particular, the expansion of the PSDB and the PRB and the reduction of the PT were at the limit of or even exceeded expectations. With 28 parties represented in the National Congress starting in 2015 (in 2014, there were 22 parties), the political scenario in the context of executive-legislative relations presents a significant potential for change. Although Rousseff was reelected, the dialogue with Congress should undergo relevant changes during the next term, which makes it essential to first know the size of the partisan forces represented in the legislature.

Figure 1 shows the evolution of the main parties in the Chamber of Deputies since 2002. A short-term comparison of 2014 and 2015 legislatures highlights a significant reduction in the PT seats, the continued shrinking tendencies in the PMDB and DEM, and the expansion of PSB and PSDB, both of which were leveraged by presidential candidacies. By the time this paper was written, the PT has the biggest number of seats (69 deputies), followed by the PMDB (65) and PSDB (54). A significant part of the governing party's losses comes from a lower number of votes obtained in São Paulo and the lack of success in

\footnotetext{
${ }^{1}$ Although 277 candidates running for federal deputy had their registries rejected, they could still run for the election while awaiting appeal. In these cases, the votes were registered, but not totaled in the count, being considered null. Therefore, for this research paper, we used data made available by the Supreme Electoral Court (TSE) on January 26, 2015.

2 We calculated a "success rate" for each projection considering the percentage of parties whose number of seats fell between the minimum and maximum margins of each study. The NECON models-http://necon.iesp.uerj.br/images/pdf/nota.pdf-showed between $39.3 \%$ and $46.4 \%$ correct classifications and varied in accordance with the specification adopted. They performed better at predicting the votes received than at the seats obtained. The DIAP predicted correctly for $57 \%$ of the parties with representation in the Chamber of Deputies.
} 
other states such as Pernambuco, where no PT representative was elected. Despite that, the PT was victorious in important electoral colleges such as Minas Gerais and Bahia due to the fact that it was impelled by the performance of the gubernatorial candidates. Although the PSDB obtained 10 more seats than what it had held in 2014 , the general result is similar to that of 2010 when it obtained 53 seats after having experienced a downward trend.

Figure 01. Parties in the Chamber of Deputies - 2002-2015

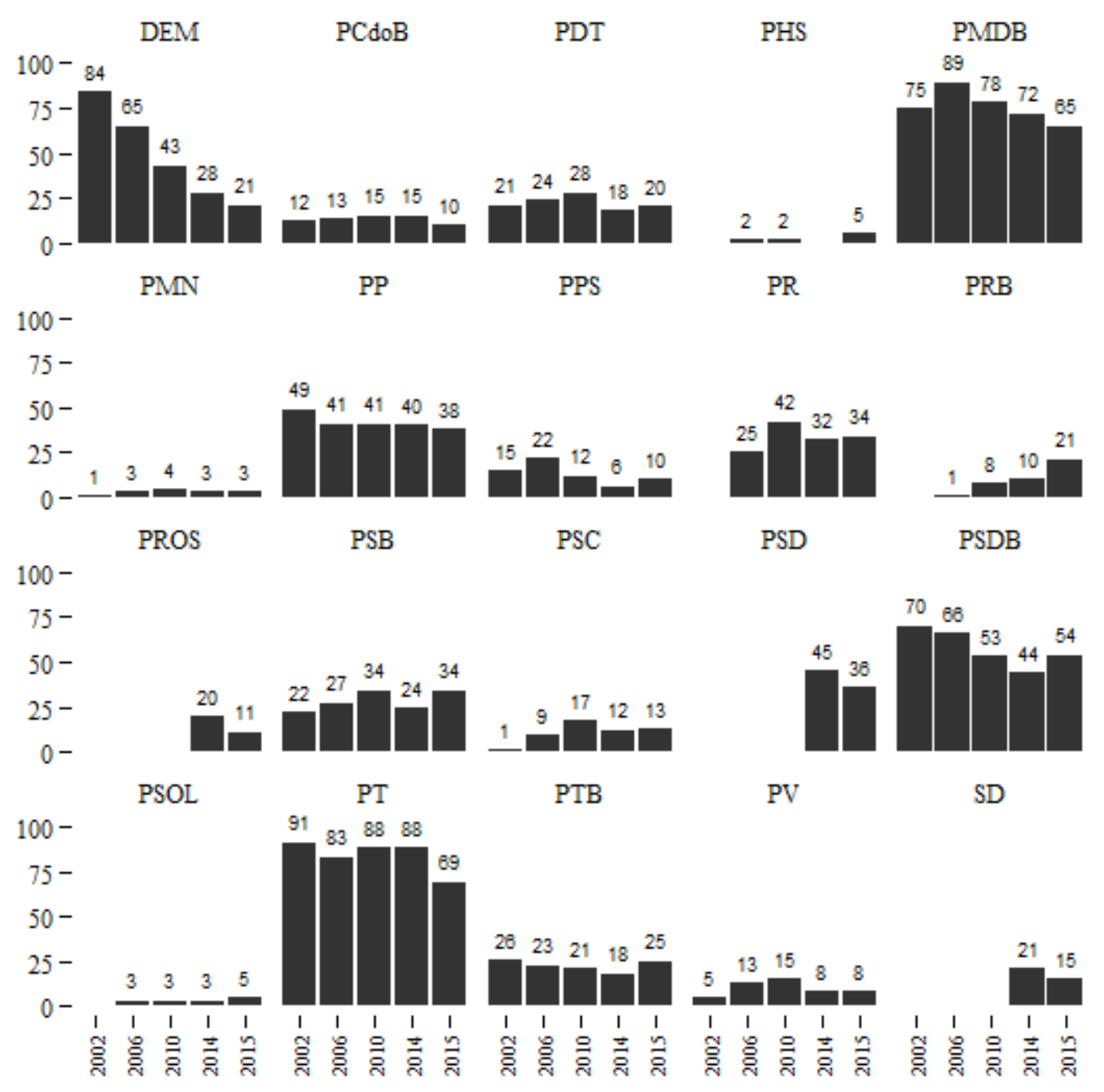

Source: SANTOS_CANELLO_CHAMBER_DATABASE.

The expansion of the PSB seems remarkable in the short-term, but once again, it is merely a recovery of the seats already obtained in 2010, after a tendency for expansion present since 2002. Mid-sized parties such as the PDT, PP, and PR suffered few quantitative changes, while the PTB and especially the PRB broadened 
their participation in the Chamber of Deputies. If the expansion of the PR in 2010 elections was connected to a greater presence of evangelical candidates, several "religious" deputies were situated, as of 2014, in the PRB-the party that proportionally increased its seats the most-as well as in the PSC. This year, the race resulted in the reduction of the parliamentary representation of new parties, (PSD, PROS, and Solidariedade), except for the PEN. Such results could indicate a suspicion toward the short-term electoral efficacy of the creation of these parties. However, in the cases of the PSD and PROS, the numbers are far from representing political failure. In fact, it is sufficient to consider that the social democrats elected the fourth largest number of seats and, as well as the PROS, has established a relevant leadership in the cabinet. Beyond what the graph shows, the growth of smaller parties (with fewer than 10 deputies) stands out, such as the PSOL, PHS, PTN, PRP, PSDC, PTC, PRTB, and PSL.

The general picture and the evolution of the Chamber of Deputies can also be summarized through some indicators of the political system fragmentation, such as the effective number of parties (ENP) and party fractionalization. Both are consistent in showing the persistent growth tendency in the dispersion of the Brazilian party system. The country has gone from an ENP of 8.42 in 2003 to 13.22 in 2015, which is one of the highest values in the world. The fractionalization index reaches the mark of 0.924 , which represents the probability of randomly choosing two federal deputies from different parties.

In the graph below, the dashed line shows the values obtained from all parties. The solid line shows the results aggregating the parties with up to 15 deputies in either a leftist or rightist block. In this way, the difference between the two numbers represents the impact of small parties on fragmentation. In other words, there is not only a tendency toward more division among the most powerful party forces but also a significant increase in the number of small parties ${ }^{3}$.

\footnotetext{
3 This indicator has its results influenced by the form in which the proportion of seats is rounded off. In the fractionalization index, for example, only parties with more than 15 deputies will singly have an effect on the third decimal place of the indicator. For an attentive reflection that contrasts the acritical use of the literature of the indicator of the effective number of parties, see Santos, 2007.
} 
Figure 02. Party fractionalization. Chamber of Deputies - 2003-2015

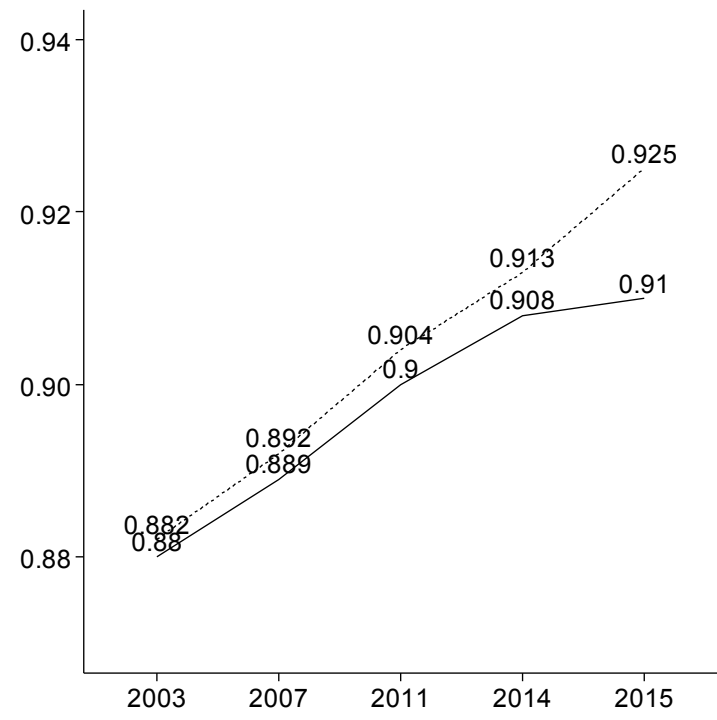

Source: SANTOS_CANELLO_FRAG1_DATABASE.

From the government perspective, the parties constituting the current set with participation in cabinet positions obtained approximately 59\% of the seats, which is less than $1 \%$ above the number of seats in 2010 , but almost $7 \%$ below this number in 2014. On the other hand, when compared with the situation before elections, the opposition has expanded, whether it was in the parties that compose the support coalition of the candidate Aécio Neves or in the members of the coalition that supported Marina Silva ${ }^{4}$ in the first round. In addition, other parties not in those coalitions, either on the right or left, as in the case of the PSOL, acted as opposition to the PT government. The total potential opposition should reach from the current $31.4 \%$ to $37.8 \%$.

In this context, without the participation of PSB or of other currently nonaligned parties, Rousseff's second term will have difficulties in obtaining $60 \%$ majority necessary to approve constitutional amendments in the Chamber of Deputies. In this case, the President will need to prepare for the opposition's unwillingness to approve reforms and policies that demand changes in the Constitution. In any case, Rousseff is likely to have a nominal majority government coalition sufficient to approve ordinary legislation and provisional measures as

4 Although the PSB recovered the seats it had lost during the legislature, the Rede Sustentabilidade-Marina Silva's group-only elected two federal deputies, which happened through other parties: Miro Teixeira (PROS-RJ) and Eliziane Gama (PPS-MA). 
long as it remains cohesive.

Figure 03. Government coalition in the Chamber of Deputies - 2010, 2014 and 2015 (\%)

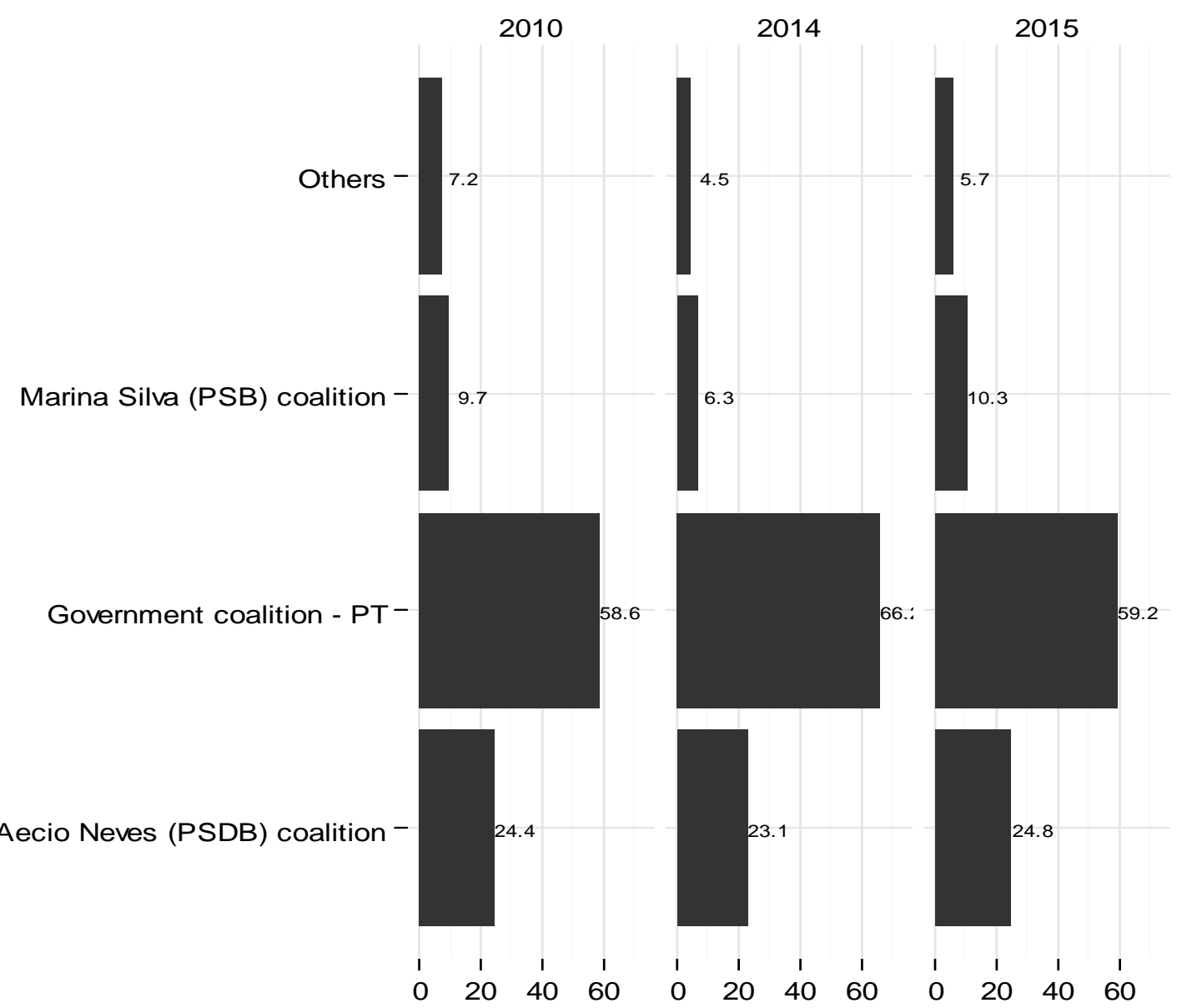

Source: SANTOS_CANELLO_CHAMBER_DATABASE.

The scenario in the Senate shows some distinctions ${ }^{5}$. The PTB and PSDB reduced their representation, whereas the PSB, DEM, and PSD expanded theirs. Three of the eight senators who contested for re-election were not successful, two of whom were veterans-Eduardo Suplicy (PT-SP) and Pedro Simon (PMDB-RS). PMDB won most of the seats disputed in this election with five senators, followed

5 The numbers of effective seats in 2015 may vary due to the senators' alternates. Our count considered the results after the second round and the following possibilities: Hélio José da Silva Lima (PSD) may be in place of Rodrigo Rollemberg (PSB-DF), elected governor; Pedro Taques (PDT), elected governor of Mato Grosso, may be replaced by José Antonio Medeiros (PPS); Eduardo Amorim (PSC), defeated in Sergipe, may return to his Senate seat, as well as Garibaldi Alves Filho (PMDB-RN), and Marta Suplicy (PT-SP), who occupied cabinet positions. 
by the PDT and PSDB with four each. Although the PMDB continued to hold the largest number of seats, important candidates of this party who were allied with ex-president José Sarney were not re-elected, such as the ex-minister of tourism, Gastão Vieira (MA) and the ex-senator Gilvam Borges (AP). In its turn, PSB expansion resulted from the three seats obtained in this election in Rio de Janeiro, Pernambuco, and Maranhão.

Figure 04. Parties in the Senate - 2014-2015

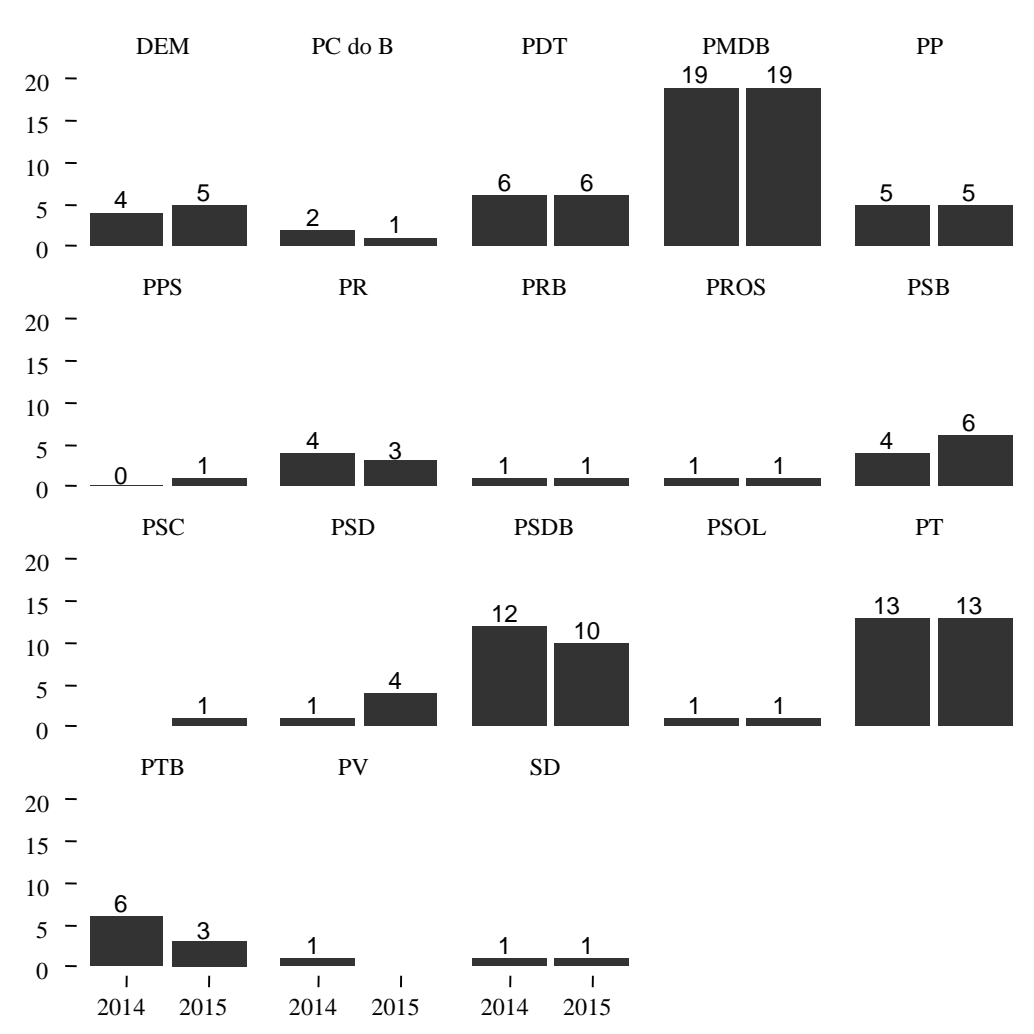

Source: SANTOS_CANELLO_SENATE_DATABASE.

Depending on the dynamics of substitutions, the parties in government coalition will slightly increase their presence in the Senate, especially the PSD, which is one of the most distant partners from the ideological or programmatic point of view relative to the government. Among the potential opposition ${ }^{6}$ groups, the PSDB support coalition gives some space to the group that allied itself to the PSB, reaching almost $10 \%$. Despite the fact that the PSDB members (Tucanos)

6 The seat attributed to PPS is available due to the replacement of senator Pedro Taques (PDT), who is elected governor of Mato Grosso. However, José Antonio Medeiros (PPS) and Paulo Pereira Fiúza Filho (PV), are still disputing a vacancy in the judicial branch. 
maintained the same position numerically, important names such as José Serra, Antonio Anastasia, and Tasso Jereissati have become members of the Senate, which will also include the democrat Ronaldo Caiado, a former federal deputy. If the parties in the government coalition are maintained, the President is likely to have the support of more than $60 \%$ - a position numerically more advantageous when compared to the Chamber of Deputies-but she may find a more critical opposition qualitatively.

In the Chamber of Deputies, there is a noticeable increase in the participation of small parties, which gives rise to parliamentary partisan fragmentation and a slight decrease in the number of parties that form the government coalition, which is smaller in comparison with the number of current seats, but very similar in size to the results from 2010. In the Senate, the main result was the slight expansion of the government coalition (not by the PT, but by an ideologically distant supporter, the PSD) and a small exchange in the field of opposition. In contrast to 2010, under PT's leadership, the coalition obtained a better numerical and proportional performance in the Senate, which also must serve as an important space for the opposition. Overall, these elections seem to indicate that the group currently in the opposition stopped the downward trend shown in previous races, except for the continuing decline of DEM in the Chamber of Deputies.

\section{The ideological setup}

Apart from the number of seats for each party, an important second dimension of our analysis is the ideological setup of Congress's new composition. In this research paper, our focus is descriptive and centered around the conjunctural debate. With such a defined scope, we will neither deal with the theoretical controversy related to the content of the distinct ideological fields nor will we deepen the methodological question about the measurement of political preferences and their multidimensionality ${ }^{7}$. Using the usual simplification of the spectrum into three positions - left, center, and right-and classifying the parties

\footnotetext{
${ }^{7}$ The literature about ideological classification is vast even for Brazil. In terms of the most recent period and for a focus on the measuring problems considering the Chamber of Deputies, it is worthwhile to see Zucco, 2009; Zucco and Lauderdale, 2011; Lucas and Samuels, 2011; Zucco and Samuels, 2014.
} 
in those terms, we will evaluate, even if imprecisely, the ideological configuration of the Congress and its dynamics over time.

After the election results were declared, part of the media soon highlighted the conservative swing of the legislative branch elected for 2015. Along this line, the first surveys prepared by the DIAP indicated a drop in the syndicalist seats (from 83 to 46 representatives) and stability in the evangelical seats (from 78 to 74 deputies). In the same way, agribusiness parliamentary members now have a greater presence according to estimates by the Agribusiness Parliamentary Front, obtaining $51 \%$ of the Chamber of Deputies. The expressive number of votes for rightist candidates such as Jair Bolsonaro (PP-RJ), Luiz Carlos Heinze (PP-RS), Celso Russomano (PRB-SP), and Cel. Alberto Fraga (DEM-DF) combined with the exit of center-left parliamentary members who acted as articulators and the reduction of the PT, especially in São Paulo, gave rise to reports about this being the most conservative Congress elected since 1964.

Figure 05. Ideological distribution. Chamber of Deputies - 2014-2015 (\%)

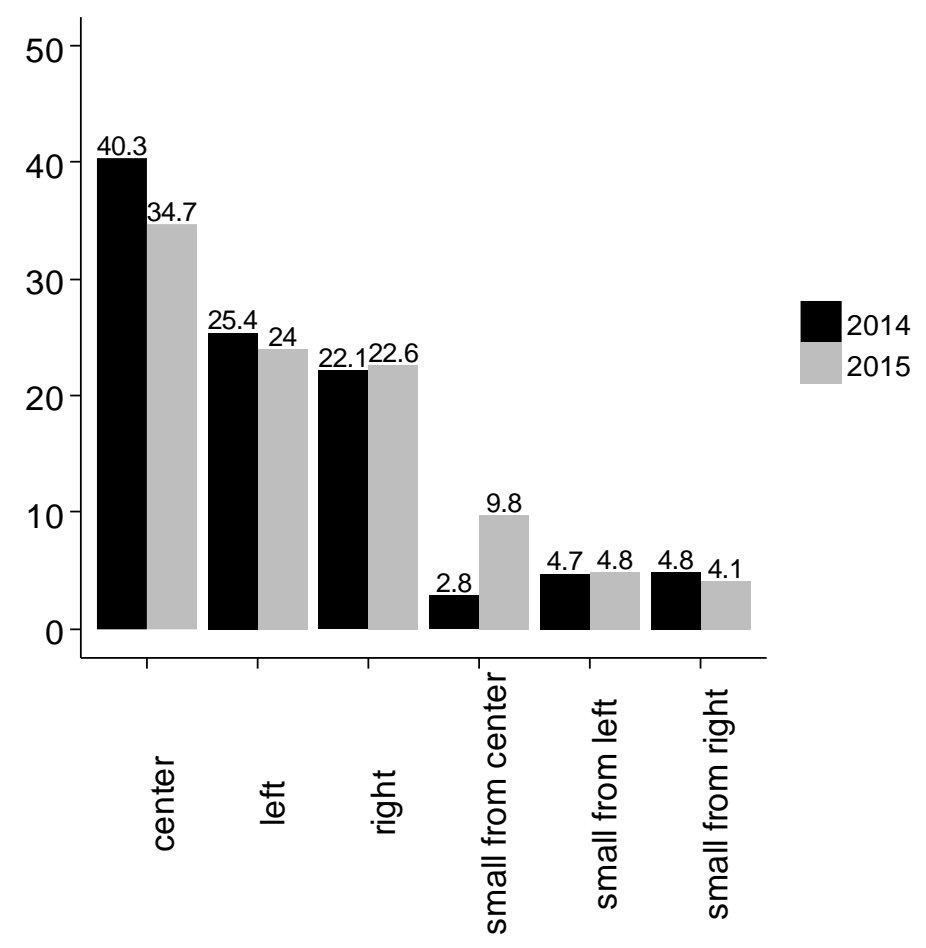

Source: SANTOS_CANELLO_CHAMBER_DATABASE. 
Figure 06. Ideological distribution. Senate - 2014-2015 (\%)

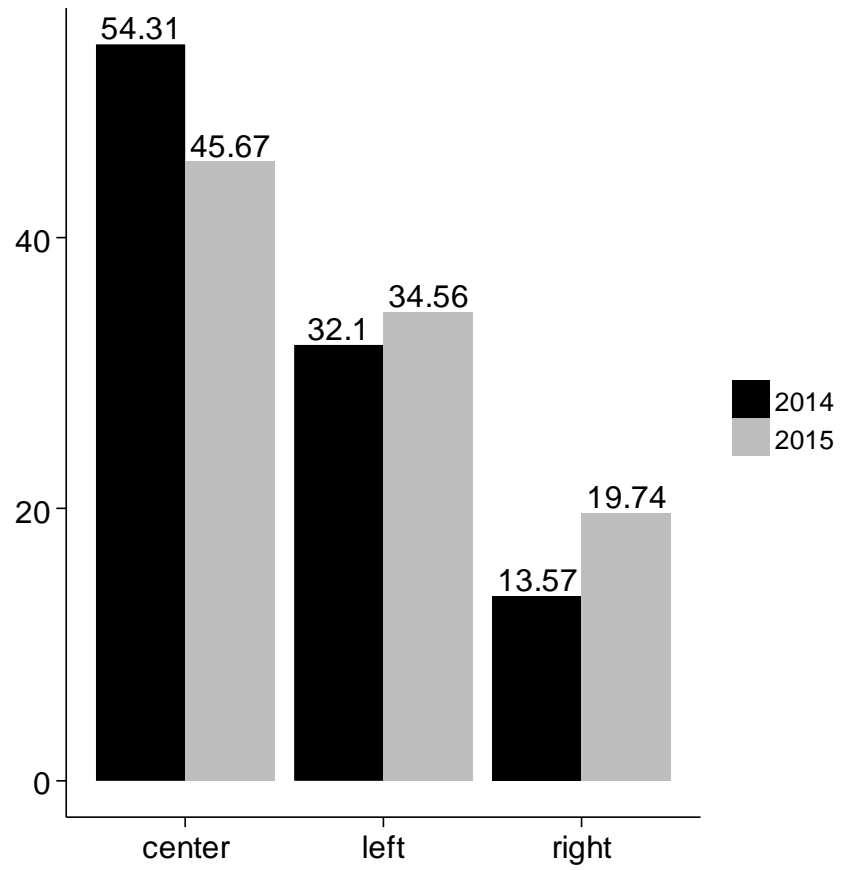

Source: SANTOS_CANELLO_SENATE_DATABASE.

In this context, without the participation of PSB or of other currently nonaligned parties, Rousseff's second term will have difficulties in obtaining 60\% majority necessary to approve constitutional amendments in the Chamber of Deputies. In this case, the President will need to prepare for the opposition's unwillingness to approve reforms and policies that demand changes in the Constitution. In any case, Rousseff is likely to have a nominal majority government coalition sufficient to approve ordinary legislation and provisional measures as long as it remains cohesive.

In short-term comparison, the decrease in the number of major leftist parties is highlighted together with a small increase in the major rightist parties as well as the fragmentation of the center in which large and mid-sized parties gave space to small ones. In both scenarios, approximately $40 \%$ of the Chamber of Deputies was situated at the center of the spectrum. The other two groups practically divide the remaining $60 \%$.The center lost space in the Senate, with a timid expansion of the left and a more significant expansion of the right. In general terms, it is possible to infer a certain general shift toward the right starting in 2015. 
Therefore, it is initially possible to recognize an advance in the conservative representation, especially when considering the profile of the parliament members who compose these parties and the composition of "thematic blocks" such as agribusiness, evangelicals, business interests, and others.

However, a slightly longer time series puts on suspicion some arguments about the magnitude of the right-wing expansion. In the Chamber of Deputies, the percentage that the right-wing achieved in last elections is significantly smaller than that obtained in the 2010 and has not even achieved the proportion seen at the end of the legislature finished in 2014. Thus, from the parties' point of view and in the simplification of ideological positions proposed here, it is confirmed that the right is stable in the Chamber of Deputies. In addition, the expansion of centrist parties with fewer than 15 seats indicates that the fragmentation of the political system has been concentrated in this field, which could be a partial effect of changes in the electoral strategies, including the PT, when it accepts center-right parties as allies.

Figure 07. The right-wing in the Chamber of Deputies - 1994-2015 (\%)

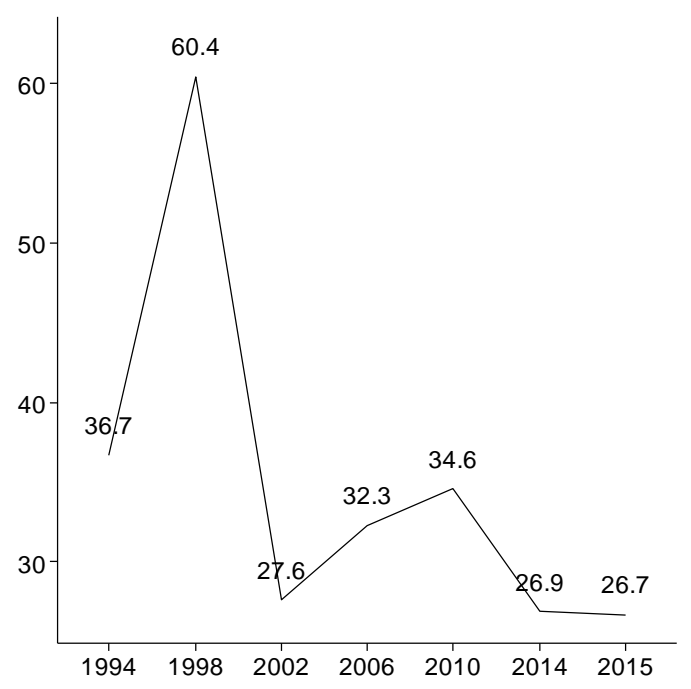

Source: SANTOS_CANELLO_CHAMBER_DATABASE.

The remaining doubt is more qualitative than quantitative. What would be the profile of this right and how would it differ from previous periods? Beyond the number of members of parliament, would its preferences be more intense than those in the past? Would there be channels able to confer more political voice and legislative resources to such a group? Would it be restricted to acting politically 
with media groups and through social media or would it be capable of advancing some concrete agenda in the legislative branch? Will the right-wing stop being simply a potential veto player using obstructionist tactics in the floor and committees sending negative signals to the government support coalition and start having more initiative in proposing and forwarding policies? Even if it is possible to answer positively to some of these questions, it cannot be ignored that the left remains powerful and, through government coalition, interacts strongly with the center. In other words, just as some leftists policies will face difficulties in Congress, the proposals coming from the right, if not really welcomed in the heterogeneous center, should be hindered by the forces of the left and center-left.

In the narratives about what characterizes the current so-called right-wing sectors in Brazil, it is possible to distinguish two dimensions in the political space: the behavioral and the economic. At first glance, one could say that a growing portion of this group has its discursive profile connected to the behavioral dimension. The significant number of votes for candidates from the public safety and evangelical "blocks" would indicate the strengthening of the right, especially in the debate over customs. However, this claim assumes, implicitly or explicitly, that not only would such opinion groups have had less strength in the last congressional term but also that they would have had little representation in the longer past. This may not be true, and should be empirically verified. An example of this problem lies in the presumption that evangelical congressmen of today-just by professing a specific faith-are necessarily more conservative than the traditional Catholics in the mid-90s on issues like abortion and same-sex marriage. For now, with no information from a longer historical series and without a more precise classification of congressional members' attitudes relative to behavioral themes, it is not possible to present firm conclusions on the subject. Future research will be able to investigate the objective changes in the Brazilian parliament in terms of ideology and positioning on relevant themes based on behavioral and attitudinal data, analyzing surveys, legislative initiatives, parliamentary amendments, speeches, and voting patterns.

The alignment between the behavioral and economic right in its parliamentary performance and in the composition of the government is also not obvious. It is not rare for some conservative members of Congress to manifest 
support for greater state participation in the economy. According to a possible interpretation, the advances of social policies in recent years, which were not accompanied by an even more liberalizing "cultural" agenda, have been possible highly due to this type of coexistence. The result would have been the formation of center-left coalitions in terms of economic and social policies, but whose members of the center (or even of the right) had reservations about adhering to left-Wing projects in the behavioral realm ${ }^{8}$. Therefore, one hypothesis for the next term is that there will be a realignment between conservatives, fine-tuning these two dimensions so as to make the advance of agendas perceived as progressive even more difficult.

From the point of view of conditions for governability, it is worthwhile to use an additional classification to examine the probable behavior of the center and other parties to the left and right, whose parliamentary performance is not always consistent with an ideologically informed program. For the lack of a better term, we will call "clientelist" or "fisiológico" (physiological) the small and mid-sized parties who, apart from showing little ideological consistency (either to the left or to the right) also see their electoral success significantly linked to their degree of access to localized public resources and tend to be governists ${ }^{9}$ (Borges, 2010). Joining this group with the PMDB (with a history of governism and centrist location in the ideological spectrum) we can measure a type of "flexible center" in the Congress.

In the Chamber of Deputies, the flexible center retains approximately $53 \%-54 \%$ of the seats in 2015 and 2014, with a reduction in the participation of the PMDB in favor of mid-sized clientelist parties. However, in the Senate, the group remains stable, with approximately $47 \%$ of the seats. It is important to note that this group is not only at the center of the spectrum, but that it also forms a majority or a quasi-majority all by itself.

\footnotetext{
8 The presence of parties with strong religious militancy in government coalition, such as the PR and the PRB, illustrates this interpretation.

${ }^{9}$ Included in this category were: PROS, PRB, PR, PSD, SD, PP, PTB, PSC, PEN, PTC, PMN, PSL, PRP, PHS, PT do B, PTN, PRTB, and the PSDC.
} 
Figure 08. Flexible center. Chamber of Deputies - 2014-2015 (\%)

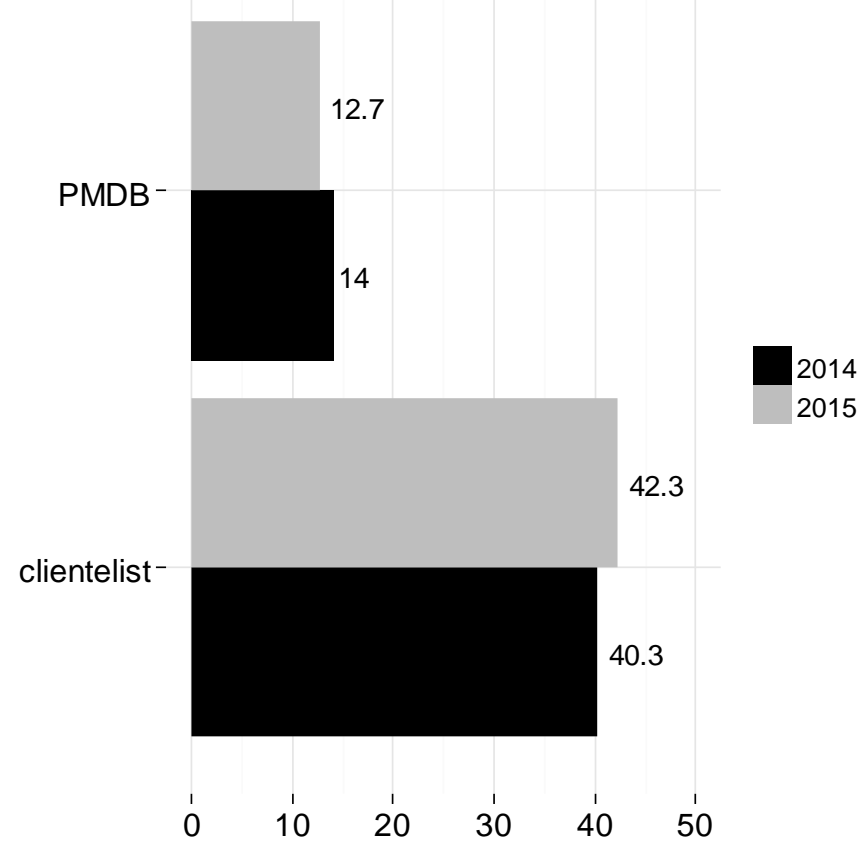

Source: SANTOS_CANELLO_CHAMBER_DATABASE.

What we call flexible center is a group that is important to the President in obtaining parliamentary support and forming the government. Simplifying the political preferences in a unidimensional spectrum and presuming reasonable levels of party discipline, the electoral results highlight that none of the candidates for the Presidency would obtain more than $30 \%$ of the Congress without the support of this powerful (although heterogeneous) group. Except in the case of a minority government that seeks to advance its agenda with ad hoc coalitions, President Rousseff, in her second term will need to negotiate with this center and use her toolbox (see RAILE, PEREIRA, and POWER, 2011) to obtain and cultivate a minimally effective and politically sustainable parliamentary base. In this way, the truth is that if we consider solely the ideological distribution in partisan terms, there are no drastic changes. In general terms, the Congress remains ideologically divided with a center that is important and pivotal, but heterogeneous in its preferences and practices. It is in this center, seduced by the poles, where the median resides and where the possibility of forwarding the political agenda will be defined. 
Without a systematic investigation of the short and long-term evolution of the political preferences of interest groups and lobbies within the parliament, the simple shift to the right that occurred in 2014 elections does not authorize adamant conclusions. It is a fact that the left stopped expanding, which could result in difficulties to advance more progressive policies, but the impacts of this electoral fact in the political agenda and in Executive-Legislative relations are still not clear. The polarization in the discourse, with emphasis on behavioral components, is not automatically reflected in the party composition of Congress relevant to any and all themes. For now, the center is not empty, but full of divisions in different dimensions of the political debate, which results in potentially diverse and apparently contradictory legislative coalitions.

Would there be any similarities in the evolution of the partisan forces of the current scenario with periods of instability and pre-crisis such as the one that took hold of the country in 1964? Yes, but with fundamental differences. The center, for example, is still strong. However, one cannot dismiss the possibility that the most dramatic aspect for the polarization of political debate is not the trajectory of the left over the last 20 years or that the right may have grown in the last elections. It is a delicate combination of a right wing with no parliamentary majority, but with more intense preferences and with different political practices, both potentially relevant factors in the next term. In the end, the future of the center and its performance in a more fragmented Congress will define the possible limits of the polarization or to the search of conciliatory agendas.

\section{Final words around governability challenges: the usual and the uncertain}

With a very narrow ${ }^{10}$ victory facing a fragmented and heterogeneous Congress, combined with an economic environment of uncertainty and many demands from pressure groups and organized sectors of the civil society, the second term of President Rousseff (PT) will be more challenging than her first. What are the possibilities and obstacles to governability for the next presidential term? How will the correlation of political forces and the institutional environment

10 The difference between the candidates Dilma Rousseff and Aécio Neves in the second round was $3 \%$ of the nominal votes, the smallest ever in the Republic. http://oglobo.globo.com/blogs/base-dados/posts/2014/10/26/a-menor-diferencadesde-republica-553265.asp 
contribute or limit the ways the government's agenda is implemented? By way of a conclusion, we present a few points that we consider decisive in the advancement of the political process starting in 2015.

The first aspect to be considered is the composition of the federal Legislative branch as of 2015. As observed, the Chamber of Deputies will have 28 parties, with its greater fractionalization resulting from an increase in the presence of small parties. The government coalition (PT, PMDB, PSD, PP, PR, PROS, PDT, PC do $B$, and PRB) reduced its nominal size, going from the current 339 seats to 304, with eight deputies less than 60\% quorum necessary to approve constitutional amendments. However, in the Senate, the government still retains, at least nominally, the relevant majorities. In general (and under a quantitative bias), the government lost support among the federal deputies and maintained a certain stability with the senators. Nevertheless, the nominal size of government coalitions is not very meaningful, seeing that it is influenced by the discipline and cohesion of the parties in the coalition, the heterogeneity of these groups in their preferences around policies, and by the quality, articulation, and intensity of the opposition.

In Brazil, ever since the government of Fernando Henrique Cardoso, it has become a recurrent practice to form over-sized coalitions. In addition to that, after Lula's victory in 2002, the creation of disconnected cabinets has become more widespread, in the sense that the parties that comprise the government are not ideologically adjacent to one another. As a consequence during the PT terms, the left versus right cleavage gave way to the government versus the opposition. Furthermore, most Congressmen themselves tend to believe that a stable and efficient government base should correspond to $60 \%$ of the legislature, so that a wide and ideologically diverse coalition would function as a type of "insurance policy" for the Executive Branch (POWER, 2011), to be capable of using distinct tools to manage the support.

In this context, a hesitant coalition may present unfavorable results in the legislative process such as: comparatively less support on roll calls of interest to the government, opinions more distant from those preferred by the President in the congressional reports, and - by strategic anticipation - a reduction in the number of Executive proposals presented to the Congress. It is interesting to note that in comparison with the performance of Lula's two terms, the first Rousseff 
administration had the lowest rate of support in the Chamber of Deputies' roll calls (45.5\%) and the smallest absolute number of proposals presented and approved, although it achieved the highest percentage of success $(65 \%)^{11}$. In other words, seeing that in general terms, the performance of the government with the Legislature was worse under Rousseff than under Lula, what would the conditions be for governability in the second term with a reduced and dubious support coalition in the Chamber of Deputies, with economic results that are inappropriate or questionable, with the ongoing Petrobrás investigations, and with an unfavorable standing in a significant portion of the media?

As for Executive-Legislative relations, the rules of the game have not changed in institutional terms; therefore, the possible differences in the results of the political process for Rousseff's second term should be evaluated on the basis of political variables related to the size and profile of the forces in parliament and their relationships as well as to contextual factors, especially economic indicators, public opinion, and the performance of controlling institutions, with the growing importance of the Judicial branch. Although party fragmentation has grown with the important influence of small parties, this is not the factor that will create major difficulties for the second term. For better or worse, Congress has been populated by various parties for a long time and also to favor their own interests, the small and mid-size parties have generally participated in parliamentary blocks and negotiated positions and policies with the government.

From an unusual perspective, this fragmentation can be interpreted as strategic to the government, whether from an electoral point of view (proportional coalitions) or even in the parliamentary sphere (formation of ad hoc legislative coalitions for specific themes). In this field, the open question is pertinent to the costs of obtaining and cultivating this support, which can vary according to the partner for each agenda. Participating in the government is related to the resources (political appointments and policies) that the Executive Branch can offer in a credible manner and to the strategies of parties themselves in the medium and

11 On the performance of Rousseff's first term with the Chamber of Deputies, see the partial research note by Santos and Canello, 2013, as well as the article in the newspaper $O$ Globo and in the blog $\mathrm{Na}$ Base dos Dados (http://oglobo.globo.com/blogs/basedados/posts/2014/11/10/desempenho-de-dilma-no-congresso-ate-agora-supera-osgovernos-lula-554324.asp), with data updated as of October, 2014. 
long-terms, either when considering the municipal elections of 2016 or the presidential and congressional races of 2018. The worsening of some indicators of the relationship with Congress seen when comparing Rousseff to Lula imposes important exceptions to the effectiveness of the strategies adopted in the first term, such as the centralization in the Presidency, without much previous negotiation about legislative agenda. In general, government formation, to obtain a parliamentary majority, the allocation of cabinet positions, and budget control represent the usual in coalition management. The scenario in the legislative branch is more restrictive when compared with the situation during the last 12 years. It demands greater political ability from the government in negotiations with its coalition and in facing the opposition.

The uncertainty for governability in the second term largely extends beyond the parliamentary arena and stems from important contextual variables such as economic and fiscal performance, the impact of the Operação Lava Jato (Petrobrás) investigations and lastly, the predisposition of the government in negotiating and communicating its arguments to the sectors that compose public opinion. Despite the fact that the anticipation of ministerial reform in the economic area for 2014 and the first measures of fiscal and budgetary contention in 2015 seek to offer positive signs to the market, it is still not entirely clear what the government's methodology will be in its relationship with Congress and what the negotiation of its agenda will be like with members who will participate in its support coalition.

Translated by Cabo Verde Submitted in December 2014 Accepted in February 2015

\section{References}

BORGES, Mariana (2010), Do parlamento ao eleitoral: do clientelismo à ideologia. Master Dissertation. Instituto Universitário de Pesquisas do Rio de Janeiro (IUPERJ). Rio de Janeiro.

DIAP (2014), Bancada sindical perde força na Câmara dos Deputados. Available at: http://www.diap.org.br/index.php?option=com_content\&view=article\&id=24 
536:bancada-sindical-perde-forca-na-camara-dos-

deputados\&catid=59:noticias\&Itemid=392. Access in December 10, 2014.

LUCAS, Kevin and SAMUELS, David (2011), A "coerência" ideológica do sistema partidário brasileiro, 1990-2009. In: POWER, Timothy J. e ZUCCO JR., Cesar. $O$ Congresso por ele mesmo: autopercepções da classe política brasileira. Belo Horizonte: Editora UFMG, 319 p.

POWER, Timothy J. (2011), O Presidencialismo de Coalizão na visão dos Parlamentares brasileiros. In: POWER, Timothy J. and ZUCCO JR., Cesar. $O$ Congresso por ele mesmo: autopercepções da classe política brasileira. Belo Horizonte: Editora UFMG, 319p.

POWER, Timothy J. and ZUCCO Jr., Cesar (2012), Elite Preferences in a Consolidating Democracy: The Brazilian Legislative Surveys, 1900-2009. Latin American Politics and Society, Vol. 54, № 04, pp. 01-27.

RAILE, Eric D.; PEREIRA, Carlos and POWER, Timothy J. (2011), The Executive Toolbox: Building Legislative Support in a Multiparty Presidential Regime. Political Research Quarterly. Vol. 64, № 02, pp. 323-334.

SANTOS, Fabiano e CANELLO, Júlio (2013), O governo Dilma na Câmara dos Deputados: comparando partidos e coalizões nos mandatos petistas. Nota de Pesquisa. Available

at: http://necon.iesp.uerj.br/images/pdf/artigos/boletim\%20necon\%202013.pd f. Access in December 10, 2014.

SANTOS, Wanderley Guilherme dos (2007), Governabilidade e Democracia Natural. Rio de Janeiro. Editora da FGV, 166 p.

VASCONCELLOS, Fábio (2014), Desempenho de Dilma no Congresso até agora supera os governos Lula. O Globo, blog Na base dos Dados. Available at: http://oglobo.globo.com/blogs/base-dados/posts/2014/11/10/desempenhode-dilma-no-congresso-ate-agora-supera-os-governos-lula-554324.asp. Acces in December 10, 2014.

ZUCCO, Cesar (2009), Ideology or What? Legislative Behavior in Multiparty Presidential Settings. The Journal of Politics. Vol. 71, № 03, pp. 1076-1092.

ZUCCO, Cesar and LAUDERDALE, Ben (2011), Distinguishing Between Influences on Brazilian Legislative Behavior. Legislative Studies Quarterly. Vol. 36, № 03, pp. 363-396.

ZUCCO, Cesar and SAMUELS, Davis (2014), The Strength of Party Labels in Brazil: Evidence from Survey Experiments. American Journal of Political Science. Vol. 51, № 01, pp. 212-235. 